\title{
PENGGUNAAN KUITANSI SEBAGAI ALAT BUKTI TRANSAKSI JUAL BELI (Ditinjau Dari Perspektif Kitab Undang-Undang Hukum Perdata)
}

\author{
*Rizki Yudha Bramantyo ${ }^{1)}$, Hary Murti ${ }^{2)}$, Niniek Wahyuni ${ }^{3)}$, Suwarno ${ }^{4)}$ \\ 1)Fakultas Hukum Universitas Kadiri, Indonesia \\ 2)Fakultas Hukum Universitas Kadiri, Indonesia \\ 3)Fakultas Hukum Universitas Kadiri, Indonesia \\ 4)Fakultas Ilmu Sosial dan Ilmu Politik Universitas Kadiri, Indonesia \\ *Email Korespondensi : rizki_bramantyo@unik-kediri.ac.id
}

\begin{abstract}
Abstrak
Penelitian ini bertujuan untuk mengetahui apakah kuitansi jual beli tebu yang dibuat petani tebu untuk kontraktor bisa dijadikan alat bukti yang menurut KUHPerdata. Dari beberapa penelitian terhadap beberapa kuitansi yang diperoleh dari kontraktor tebu, disimpulkan bahwa kuitansi jual beli yang dibuat memiliki bebrapa kelemahan. Kurang lengkapnya isi dari kuitansi jual beli tersebut akhirnya membuat lemah jika dugunakan sebagai alat bukti. Keadaan ini berimbas pada lemahnya posisi kontraktor tebu jika dikemudian terjadi wanprestasi dari transaksi tersebut. Penulis mengusulkan bentuk kuitansi yang dirasa lebih sesuai dengan transaksi jual beli tebu, dengan manambahkan baris isian: warga untuk alamat petani, seluas/sebanyak untuk menyatakan luasnya lahan tebu yang dijual, atau seberapa banyak tebu yang dijual, lokasi lahan untuk menjelaskan lokasi lahan tebu secara terperinci, bats batas untuk menyatakan batas sekeliling lahan, harga untuk jumlah harga yang disepakati, ketentuan untuk ketentuan tambahan dalam transaksi, dan baris untuk saksi I dan saksi II.
\end{abstract}

Kata Kunci: Kuitansi; Petani Mandiri; Kontraktor Tebu

\begin{abstract}
This study aims to determine whether the receipt of sale and purchase of sugarcane made by sugar cane farmers for contractors can be used as evidence according to the Civil Code. From several studies on several receipts obtained from sugar cane contractors, it was concluded that the sale and purchase receipts made have a number of weaknesses. The incompleteness of the contents of the sale and purchase receipt ultimately makes it weak if used as evidence. This situation has an impact on the weak position of the sugar cane contractor if there is a default from the transaction. The author proposes a form of receipt that is deemed more appropriate to the sale and purchase transaction of sugar cane, by adding a fill line: residents to address farmers, area / as much to
\end{abstract}


state the extent of sugarcane land that is sold, or how much sugarcane is sold, the location of the land to explain the location of sugarcane land in in detail, the boundary to state the boundary around the land, the price for the agreed price amount, provisions for additional provisions in the transaction, and lines for witness I and witness II.

Keywords: Receipts; Independent Farmers; Sugar Cane Contractors

\section{PENDAHULUAN}

Tahun 2020 tidak bisa dipungkiri lagi bahwa pertumbuhan penduduk Indonesia sangat pesat (1,49\%/tahun) itu sama dengan rata-rata setiap keluarga memiliki 2 sampai 3 anak dan jika dijumlah menjadi 4,5 juta jiwa/tahun (Latisia, 2017). Era otonomi daerah pada dasarnya memberikan porsi kue ekonomi yang lebih besar kepada daerah untuk mendorong kemandirian daerah. Artinya daerah kini memiliki peran lebih untuk meningkatkan ekonomi lokal di daerahnya sendiri tanpa harus terus bergantung kepada pemerintah pusat (Marwanto \& Suwarno, 2019). Pemerintah pusat memberi kewenangan otonomi pada daerah berupa desentraliasi baik kabupaten maupun kota yangberdasarkan pada azas desentralisasi dalam mewujudkan otonomi yang luas, nyata dan bertanggung jawab, adanya otonomi daerah pada kabupaten dan kota membuat keleluasaan untuk pengembangan potensi ekonomi di wilayahnya berdasarkan model yang sesuai dengan keinginan dan harapan masyarakat (Hanum, 2019).

Jawa Timur merupakan salah satu provinsi yang jumlah penduduknya terpadat di Indonesia, meskipun padat, Jawa Timur merupakan salah satu provinsi yang memiliki lumbung tanaman tebu dan hampir setengah dari produksi tebu di Indonesia ada pada Jawa Timur yaitu sebesar 48\%. Sentra produksi tebu Jawa Timur ada pada Malang dan Kediri. Dengan hal ini, maka sistem perdagangan tebu sangat dinamis di Kediri. Kontraktor tebu adalah orang yang memiliki kontrak dengan pabrik gula, untuk mengirimkan tebu miliknya lalu digiling di pabrik gula. Kontraktor tebu mendapat fasilitas kredit dan pupuk dari pabrik gula dengan perantara koperasi petrani tebu. Dalam proses pembelian tebu terjadilah hubungan hukum antara pihak petani mandiri dengan kontraktor. Dalam hubungan antara kontraktor dengan petani tebu mandiri, ada pihak yang disebut perantara atau makelar. Sebagai wakil penjual atau petani mandiri maka tugasnya adalah mencarikan pembeli tebu milik petani mandiri, dan dia menerima fee dari petani mandiri. 
Peranan makelar sangat penting dan dominan, dalam usaha memperlancar transaksi penjualan tebu. Biasanya dalam transaksi ini, kontraktor tebu dan petani tabu tidak pernah bertemu, semua tergantung makelar. Jika terjadi kesepakatan harga, maka kontraktor membayar sebagian harga tebu sebagai tanda jadi melalui makelar, dan kekurangan akan dibayar dilain waktu .

Sebagai bukti dibuatlah kuitansi penyerahan uang yang ditandatangani makelar, kuitansi beserta uang diserahkan ke petani tebu mandiri. Kuitansi ditandatangani oleh petani tebu mandiri sebagai penjual. Selanjutnya petani diserahkan ke kontraktor. Berlandaskan pokok pikiran bahwa setiap perjanjian harus dilakukan secara sah, menggunakan bukti yang sah kuat jika dibutuhkan ketika adanya sengketa di kemudian hari.

\section{TINJAUAN PUSTAKA}

\section{Teori Perjanjian}

Perjanjian yang paling dasar terdapat pada pasal 1313 KUHPerdata yaitu suatu perbuatan satu orang atau lebih mengikatkan dirinya terhadap satu orang atau lebih. Sedangkan menurut (Bahroni, 2018), perjanjian diartikan sebagai suatu perbuatan hukum mengenai harta benda kekayaan antara dua pihak, dimana satu pihak berjanji atau dianggap berjanji untuk melaksanakan suatu hal atau untuk tidak melakukan suatu hal, sedangkan pihak lain berhak menuntut pelaksanaan janji itu.

Dari pendapat-pendapat diatas, dapat disimpulkan bahwa didalam perjanjian terdapat beberapa unsur (Azhari, 2020) yaitu:

1. Ada pihak pihak. Pihak disini adalah subjek perjanjian sedikitnya dua orang atau badan hukum dan harus mempunyai wewenangmelakukan perbuatan hukum seseuai yang ditetapkan oleh undang undang.

2. Ada persetujuan antara pihak-pihak, yang bersifat tetap dan bukan suatu perundingan.

3. Ada prestasi yang akan dilaksanakan. Hal ini dimaksudkan bahwa prestasi merupakan kewajiban yang harus dipenuhi oleh pihak-pihak sesuai dengan syarat perjanjian. 
4. Ada tujuan yang akan dicapai. Hal ini dimaksudkan bahwa tujuan para pihak hendakya tidak bertentangan dengan ketertiban umum. Kesusilaan dan undang-undang.

5. Ada bentuk tertentu, lisan atau tulisan. hl ini berarti bahwa perjanjian bisa dituangkan secara lisan maupun tulisan. hal ini sesuai ketentuan undangundang yang menyebut bahwa hanya dengan bentuk tertentu suatu perjanjian mempunyai kekuatan mengikat dan bukti yang kuat.

\section{Asas-asas Perjanjian}

Dalam membuat perjanjian, maka perlu memperhatikan asas asas yang ada dalam perjanjian agar perjanjian yang dibua menjadi perjanjian yang baik. Dalam KUHPerdata terdapat beberapa asas yaitu: asas kebebasan berkontarak (freedom of contract), asas konsensualisme (consesualism of contract), asas kepastian hukum atau pacta sun servada, asas etikat baik (good faith), asas kepribadian (personality) (Dominika \& Kawuryan, 2018).

\section{Asas Kebebasan Berkontrak}

Adalah asas yang menyatakan bahwa para pihak dalam suatu perjanjian bebas untuk menentukan materi atau isi dari perjanjian sepanjang tidak bertentangan dengan ketertiban umum, kesusilaan dan keputusan. Asas ini tercermin jelas pada pasal 1338 KUH Perdata yang menyatakan bahwa "Semua perjanjian yang dibuat secara sah mengikat sebagai undang-undang bagi mereka yang membuatnya". "Semua perjanjian..." memiliki arti perjanjian apapun dan diantara siapapun. Tetapi kebebasan ini tetap dalam syarat-syarat yanng berlaku, tidak melanggar hukum (UUD) dan kesusilan seperti pornografi, porno aksi, serta melanggar krtertiban umum (Setiono, 2018).

\section{Asas Konsensualisme}

Yaitu bahwa suatu perjanjian dan perikatan yang timbul, telah lahir sejak detik tercapainya kesepakatan, selama para pihak dalam perjanjian tidak menentukan lain. Asas ini sesuai dengan ketentuan pasal $1320 \mathrm{KUH}$ Perdata mengenai syarat syarat sahnya perjanjian (Bramantyo et al., 2020).

\section{Asas Kepastian Hukum (Pacta Sun Servanda)}


Adalah suatu asas yang menyatakan bahwa hakim atau pihak ketiga harus menghormati substansi kontrak yang dibuat oleh para pihak, sebagaimana layaknya sebuah undang-undang, mereka tidak boleh melakukan intervensi terhadap substansi kontrak yang dibuat oleh para pihak (Salim, 2003). Pacta sun servanda berasal dari bahasa latin yag berarti “Janji harus ditepati” (agreements must be kept), sehingga dalam hukum positif rumusan normanya menjadi: setiap perjanjian yang dibuat secara sah berlaku sebagai undang-undang bagi ereka yang dibuatnya.

Dalam KUH Perdata asas kepastian hukum/ pacta sun servanda diatur dalam pasal 1338 ayat 1 dan 2 KUH Perdata yaitu:

1. Semua persetujuan yang dibuat sesuai dengan undang undang yang berlaku sebagau undang undang bagi mereka yang membuatnya

2. Persetujuan itu tidak dapat ditarik kembali selain dengan kesepakatan kedua belah pihak, atau karena alasan alasan yang ditentukan oleh undang undang.

\section{Asas Itikat Baik (Good Faith)}

Menurut (Muhammad, 2017) merupakan salah satu sendi terpenting dalam hukum perjanjian. Selanjutnya Muhammad berpendapat bahwa perjanjian denga itikat baik adalah melaksanakan perjanjian dengan mengandalkan norma-norma kepatutan dan kesusilaan. Berdasarkan pengertian itikat baik dalam perjanjian tersebut maka unsur yang pertama adalah kejujuran. Kejujuran para pihak dalam perjanjian ini meliputi pada keujuran atas identitas diri dan kejujuran atas kehendak dan tujuam para pihak (Abdurrahman \& Wahidin, 1985).

\section{Asas Kepribadian (Personality)}

Artinya tidak seorangpun dapat mrngadakan perjanjian, kecuali untuk dirinya sendiri. Hal ini dapat dilihat dalam pasal 1315 dan pasal 1340 ayat 1 KUH Perdata. Pasal 1315 KUH Perdata menegaskan: "Pada umumnya seseorang tidak dapat mengadakan perikatan atau perjanjian selain untuk dirinya sendiri”. Inti ketentuan ini sudah jelas bahwa untuk mengadakan suatu perjanjian, orang tersebut harus untuk kepentingan dirianya sendiri (Windradi \& Setiono, 2019). 


\section{Perjanjian Tertulis dan Lisan}

Perjanjian tertulis yaitu suatu perjanjian yang dibuat oleh para pihak dalam bentuk tulisan. perjanjian tertulis ada yang berupa akta dibawah tangan dan akta otentik. Akta dapat diartikan sebagai surat yang bertanggal dan diberi tangan yang memuat peristiwa peristiwa yang menjadi dasar suatu hak atau perikatan yang digunakan untuk pembuktian (Mohammad, 1986). Berdasarkan ketentuan pasal 1867 KUHPerdata suatu akta dibagi menjadi 2 yaitu 1) Akta dibawah Tangan (onderhands). Akta dibawah tangan adalah akta yang dibuat tidak dihadapan pejabat yang berwenang atau notaris. Akta ini yang dibuat dan ditandatangani oleh para pihak yang membuatnya. Apabila suatu akta dibawah tangan tidak disangkal oleh para pihak, maka berarti mereka mengakui dan tidak menyangkal kebenaran kebenaran apa yang tertulispada akta dibawah tangan tersebut, sehingga sesuai pasal 1857 KUHPerdata akta dibawah tangan tersebut memeperoleh kekuatan pembuktian yang sama dengan suatu akta otentik. Akta dibawah tangan terdiri dari: a. Akta dibawah tangan biasa. 2) Akta Waarmaken, adalah suatu akta dibawah tangan yang dibuat dan ditandatangani oleh para pihak, kemudian didaftarkan pada notaris.

Sedangkan Perjanjian lisan adalah suatu perjanjian yang dibuat oleh para pihak dalam wujud lisan (cukup kesepakatan para pihak) (Purwanto, 2009).

\section{METODE PENELITIAN}

Jenis data yang digunakan dalam penelitian ini adalah data kualitatif, yaitu data yang diperoleh dari studi pustaka, dari berbagai sumber yang berkaitan dengan penulisan penelitianan ini. Data kualitatif adalah data yang berbentuk kata kata, bukan dalam bentuk angka. Dalam penulisan penelitian ini, penulis menggunakan metode studi kepustakaan, yaitu menelaah bahan bahan pustaka seperti buku, artikel di internet yang berkaitan dengan bahan penulisan penelitian ini. Juga melakukan telaah kuitansi jual beli tebu milik petani tebu yang biasanya digunakan.

Data yang digunakan dalam penulisan penelitian ini adalah data sekunder, yaitu semua yang berkaitan dengan perjanjian alat bukti, perjanjian jual beli yang diatur dalam KUH Perdata, dan teori teori hukum yang terkait, juga kuitansis milik kontraktor tebu. Lokasi dalam penelitian ini dibatasi hanya berasal dari petani di Desa jabang Kecamatan 
Kras Kabupaten Kediri, hal ini dilakukan dengan alasan kemudahan memperoleh data karena merupakan daerah tempat tinggal penulis. Disamping itu pembatatasan ini karena penulis yakin bahwa desa tersebut dapat mewakili kejadian jual beli tebu di wilayah

\section{HASIL DAN PEMBAHASAN}

\section{Kuitansi Sebagai Bukti}

Adanya kuitansi baik kelompok A maupun kuitansi kelompok B menunjukkan bahwa telah terjadi penyerahan uang dari kontraktor tebu. Pada kelompok A jelas secara nyata bahwa uang tersebut telah diterima oleh petani atau pihak penjual. Sedangkan pada kelompok kuitansi B, terjadi penyerahan uang dari kontraktor kepada petani melalui perantara dengan pertanyaan yang belum terjawab apakah uang tersebut sampai kepada petani/penjual sesuai yang disepakati atau tidak. Kuitansi ini diharapkan bisa menjadi bukti tertulis, yang sekalipun bukan termasuk akta otentik, tetapi memiliki kemampuan sebagai alat bukti yang sah jika dikemudian hari terjadi sengketa diantara mereka.

\section{Kuitansi Sebagai Perjanjian}

Dilihat dari sisi kuitansi juga berfungsi sebagai perjanjian, maka dapat dikatakan bahwa kuitansi merupakan sebuah indikasi telah terjadinya perjanjian antar orang yang namanya sebagai pembayar dan orang yang menerima sejumlah uang. Sebagaimana yang tercantum dalam kausul tujuan pembayaran adalah untuk pembayaran pembelian tebu sebagaimana yang telah disepakati.

Menurut asas konsensualisme, suatu perjanjian dan perikatan yang timbul sejak detik tercapainya kesepakatan, selama para pihak dalam perjanjian tidak menentukan lain. Sehingga pada saat ditandatangani kuitansi antara dua pihak telah terjadi perjanjian. Sebenarnya perjanjian sudah terbentuk ketika kedua belah pihak menyatakan setuju dengan harga sesuai negoisasi sekalipun beluum dilakukan pembayaran. Karena prinsip terjadinya penjualan adalah adanya kata sepakat antara kedua belah pihak.kuitansi hanya mempertegas adanya perjanjian sebelumnya. 
Pada kuitansi kelompok A, secara jelas kesepakatan dinyatakan dengan kesediaan petani menandatangani pembayaran dan dari pihak kontraktor dinyatakan dengan kesediaan membayar sejumlah uang.

Sedangkan pada kuitansi keompok B, adanya kesepakatan hanya benar-benar diketahui oleh perantara. Disini peranan perantara sangat besar, keamanan transaksi sangat tergantung padanya. Benar tidaknya pihak petani sudah sepakat atau belum hanya diketahui perantara.

\section{Pemenuhan Syarat Subjektif Perjanjian}

Pada kuitansi kelompok A, kuitansi ditandatangani oleh petani tebu/penjual sendiri. Pada kuitansi kelompok A secara jelas bahwa kesepakatan sudah terjadi. Pada kuitansi kelompok B, kuitansi hanya ditandatangani oleh perantara. Dengan keadan ini kuitansi kelompok B tidak bisa menunjukkan adanya kesepakatan antara kedua pihak. Pada kelompok B, pihak penjual/petani tebu tidak ikut tanda tangan pada kuitansi. Hanya perantara yang menandatangani sebagai bukti dia menerima uang dari kontraktor untuk disampaikan kepada petani tebu sebagai penjual. Dalam hal ini tidak ada pihak yang berwenang sebagai penjual. Jadi disimpulkan bahwa kelompok B syarat sahnya perjanjian yang berdua menurut KUH Perdata yaitu cakap membuat menurut hukum. Dengan tidak terpenuhinya syarat subjektif dalam kuitansi B, maka kedudukan kuitansi B masih sebagai alat perjanjian yang lemah. Karena kuitansi kelompok B sekalipun tidak langsung batal tetapi dapat dimintakal pembatalan bagi pihak yang dirugikan. Tetapi apabila tidak ada pihak yang mengajukan pembatalan maka perjanjian ini tetap berlaku.

\section{Pemenuhan Syarat Objektif Perjanjian}

Syarat objektif sahnya perjanjian menurut KUH Perdata adalah bahwa suatu perjanjian haruslah mempunnyai pokok suatu barang yang paling sedikit ditentukan jenisnya dan suatu sebab yang siperkenalkan yang berarti bahwa suatu perjanjian haruslah dibuat dengan tujuan dan alasan yang sesuai dengan hukum yang berlaku Baik kuitansi A maupun B mempunyai objek yang jelas yaity tebu. Dan juga memiliki alasan serta tujuan yang tidak melanggar hukum yang berlaku. Jadi dapat disimpulkan bahwa kuitansi kelompok A dan kuitansi kelompok B memenuhi syarat objektif dari sebuah perjanjian. 
Kuitansi kelompok A memenuhi semua syarat sahnya suatu perjanjian menurut KUH Perdata, baik syarat subjektif maupun objektif. Sehingga kuitansi kelompok A merupakan suatu perjanjian yang sah antara kontraktor dengan petani tebu. Perjanjian ini merupakan perjanjian dengan objek perjanjian yaitu tebu. Kuitansi kelompok A merupakan bukti yang kuat jika dikemudian hari terjadi masalah atau wan prestasi. Sedangkan kuitansi kelompok B merupakan perjanjian yang tidak memenuhi syarat subjektif perjanjian menurut KUH Perdata. Sehingga dapat dibuatkan pembatalan oleh salah satu dari para pihak. Jika perjanjian itu tidak dimintakan untuk dibatalkan maka perjanjian tetap berlaku diantara para pihak.

Berdasarkan pengamatan yang menjadi sebab tidak sempurnanya pembuatan kuitansi adalah dominanya peran perantara. Dimana perantara selainn berperan sebagai perantara yang menjembatani antara penjual dan pembeli, juga berperan sebagai saksi dan bahkan mewakili penjual untuk menerima pembayaran.

Padahal peranan perantara atau makelar menurut KUHD adalah orang orang yang bekrja kepada pihak lain untuk menutup persetujuan-persetujuan atas nama orang yang menyuruhnya atau pengusaha. Jadi sebagai perantara atau makelar, tidak berhak bertanda tangan atas nama yang menyuruh, tidak boleh bertindak atas nama dirinya sendiri.

Hal lain yang memerlemah kuitansi untuk menjadi bukti adalah pengisian kolom yang tidak lengkap. Contohnya adalah penulisan objek jual beli yang kurang terperinci. Objek jual beli dalam kuitansi tercantum dalam tujuan pembayaran. Yang menjadi hal di kuitansi ini adalah tebu yang menjadi pokok perjanjian. Sekalipun hal tentunya terpenuhi karena tidak lengkap mencantumkanya maka jika terjadi masalah akan menambah kesulitan untuk membuktikanya atas objek yang menjadi pokok perjanjian.

Dalam hal saksi, kuitansi yang hanya ditandatangani oleh satu orang yang perantara tidak bisa dipercaya. Seperti KUH Pedata pasal 1905 yang berisi: keterangan satu saksi saja tanpa alat bukti tidak dapat dipercaya, disebut juga unus testis mullus testis. Ketika hanya ada satu orang saksi maka dalam transaksi tersebut akan terjadi masalah, maka kedudukan pembeli sangat lemah. Yang bisa dilakukan adalah hanya mengandalkan perantara untuk membuktikan adanya transaksi jual beli tersebutdan memastikan semua perjanjian disepakati semua pihak. 
Beberapa kejadian yang pernah terjadi justru perantara yang bermasalah. Seperti menawarkan tebu yang tidak ada, tebu yang tidak dikuasakan kepada dirinya, tebu yang sudah dijual beberapa kali, uamh pembayaran yang tidak seluruhnya diserahkan ke pemeilik tebu. Apabila sudah terjadi hal tesebut segala kerugian akan ditanggung oleh kontraktor karena posisi kontraktor sangat lemah dalam transaksi ini.

Sebuah keberuntungan yang masih berpihak kepada kontraktor adalah masih banyaknya petani dan perantara yang jujur, dan mengsnggsp kesepakatan lisan sebagai suatu hal yang sakral dan harus ditepati. Pembuatan kuitansi tidak sempurna ini bisa terjadi karena:

1. Besarnya kepercayaan kontraktor tebu dan perantara

2. Kurangnya pemahaman dari kontraktor bahwa kuitansi merupakan bukti yang krusial jika dikemudian hari terjadi war prestasi atau perselisihan antar pihak

3. Desain kuitansi yang bentuknya umum, sehingga membuat kontraktor trbu membuat kuitansi yang tidak terperinci.

Untuk itu perlu kiranya untuk meningkatkan pengetahuan pihak-pihak yang terlibat dalam jual beli tebu tentang apa fungsi kuitansi, bagaimana cara mengisinya dan siapa yang harus bertanda tangan. Pengisian yang lengkap pada kuitansi akan memperkuat kedudukan kuitansi baik sebagai perjanjian maupun sebagai bukti transaksi. Untuk itu penulis membuat desain kuitansi yang dapat digunakan dalam jual beli tebu, dengan memberikan kolom-kolom yang berisi informasi yang penting dalam jual beli tebu. Sehingga kuitansi jual beli tebu menjadi lebih terperinci.

\section{KESIMPULAN DAN SARAN}

\section{Kesimpulan}

Dari uraian pembahasan dan analisa yang telah dilakukan, dapat disimpulkan sebagai berikut:

1. Kuitansi dapat digunakan alat bukti adanya jual beli tebu dan juga sebagai bukti adanya perjanjian yang sah karena memenuhi syarat sahnya prjanjian menurut pasal menurut pasal 1320 KUH Perdata. 
2. Kuitansi akan menjadi alat bukti kurang sempurna apabila suatu perjanjian dalam pembuatanya tidak memenuhi syarat subjek perjanjian. Hal ini karena kuitansi tidak ditandatangani oleh pemilik tebu sendiri. Akibat kuitansi ini bisa dimintakan pembatalan oleh para pihak jika dianggap merugikan.

3. Sebenarnya bentuk kuitansi yang ada dipasaran saat ini cukup memenuhi kebutuhan jual beli tebu jika pembuatanya bisa lebih teliti dan dibuat dengan benar. Seperti pengisian tujuan pembayaran dengan komplit dan ditandatangani oleh pihak dan saksi yang sah. Tetapi ada baiknya juga dibuat kuitansi khusus untuk jual beli tebu dengan memberikan tempat isian yang detail, yang meliputi: pemilik tebu, alamat pemilik, luas lahan, loksai lahan, batas lahan dan ketentuan tambahan yang telah disepakati bersama jika ada.

\section{Saran}

Untuk menghindari pembuatan kuitansi yang tidak sah, maka penulis mengusulkan beberapa hal yang bisa dilakukan, yaitu:

1. Diadakan penyuluhan tentang pentingnya pembuatan bukti transaksi yang sah kepada petani dan kontraktor tebu.

2. Diadakan penyuluhan tantang bagaimana pembuatan perjanjian menurut pasal 1320 KUH Perdata

\section{REFERENSI}

Abdurrahman, \& Wahidin, S. 1985. Beberapa Catatan Tentang Hukum Jaminan dan Hakhak Jaminan Atas Tanah.

Azhari, R. N. 2020. Understanding the Contents of Indonesian Civil Law. HeinOnline.

Bahroni, A. 2018. Hak Penambangan Pasir Oleh Masyarakat Lokal di Kecamatan Plosoklaten Kabupaten Kediri. Transparansi Hukum, 1(2), 152-168.

Bramantyo, R. Y., Pujiono, B., \& Sudarmanto, H. L. 2020. Tindak Pidana Pencemaran Nama Baik Yang Dilakukan Melalui Media Sosial Menurut Undang-Undang Nomor 19 Tahun 2016 Tentang Informasi Dan Transaksi Elektronik. Transparansi Hukum, $3(2)$.

Dominika, R. W., \& Kawuryan, E. S. 2018. Perjanjian Beli Kembali (Buy Back Guarantee) Antara Pengembang Dan Bank Dalam Penyelesaian Masalah Kredit Macet. Transparansi Hukum, 1(1). 
Hanum, F. 2019. Analisis Pelaksanaan Peraturan Walikota No.40 Th. 2014 Tentang Pedoman Program Fasilitasi Pemberdayaan Masyarakat Di Kecamatan Mojoroto Kota Kediri. Mediasosian, Vol. 3(1), hal. 15-27.

Latisia, S. 2017. Strategi Pemberdayaan Usaha Mikro, Kecil dan Menengah (UMKM) di Kota Kediri. Mediasosian, Vol. 1(2), hal. 62-75.

Marwanto, I. H., \& Suwarno, S. 2019. Reformasi Birokrasi Daerah: Variasi Inovasi Birokrasi Perizinan Pasca Otonomi Daerah. Mediasosian, Vol. 2(2).

Muhammad, A. 2017. Hukum perdata indonesia.

Purwanto, H. 2009. Keberadaan Asas Pacta Sunt Servanda dalam Perjanjian Internasional. Mimbar Hukum-Fakultas Hukum Universitas Gadjah Mada, 21(1), $155-170$.

Salim, H. S. 2003. Hukum kontrak: Teori dan teknik penyusunan kontrak. Sinar Grafika.

Setiono, G. C. 2018. Jaminan Kebendaan Dalam Proses Perjanjian Kredit Perbankan (Tinjauan Yuridis Terhadap Jaminan Benda Bergerak Tidak Berwujud). Transparansi Hukum, Vol. 1(No. 1).

Windradi, F., \& Setiono, G. C. 2019. Konsekuensi Yuridis Jual Beli Tanah Yang Dibebani Hak Tanggungan. Transparansi Hukum, Vol 1(1), 45-66. 